\title{
A dominação carismática em regimes democráticos
}

Roger Laureano'

\section{Resumo}

O artigo busca analisar a possibilidade de conciliar o conceito weberiano de dominação carismática com as democracias contemporâneas e com líderes que não rompem com as normas institucionais. A partir da análise exegética de Weber, chegamos a uma definição de dominação carismática que se baseia primordialmente na relação afetiva dos seguidores com o líder em razão de seu caráter extraordinário. Contestando outras interpretações, argumentamos que essa definição é compatível com líderes democráticos sem perder a eficiência de sua aplicação a casos subversivos. Finalmente, para além de Weber, apresentamos algumas possíveis aplicações do conceito a partir de três elementos ideais-típicos: intensidade, difusão e direção do carisma. Esse modelo pode incluir carismas autoritários e antiautoritários e explicar o comportamento dos seguidores em medidas que envolvam os líderes.

Palavras-chave: Dominação carismática. Democracia. Weber. Liderança.

\section{Introdução}

O conceito de carisma, tornado célebre nas ciências sociais pela obra de Max Weber, já foi instrumentalizado de maneiras muito díspares. A disputa existe na própria exegese de Weber; primeiramente se o clássico alemão modificou o significado de carisma ao longo de sua obra, depois nas pleiteias hermenêuticas sobre a própria definição do conceito. Mas a polêmica não se resume a uma disputa exegética. A popularidade difundiu o seu uso gerando atualizaçóes, remendos e mudanças (SHILS, 1965);

I Doutorado do Programa de Pós-Graduação em Sociologia e Ciência Política (PPGSP) da Universidade Federal de Santa Catarina (UFSC). Professor Titular da FUCAP-Univinte.

\section{(c) EY}

Direito autoral e licença de uso: Este artigo está licenciado sob uma Licença Creative Commons. Com essa licença você pode compartilhar, adaptar, para qualquer fim, desde que atribua a autoria da obra, forneça um link para a licença, e indicar se foram feitas alterações. 
logo, angariou acusaçóes de abuso do termo e anarquia conceitual. Alguns chegaram a propor o seu abandono. Spinrad escreveu que "talvez seria salutar a total eliminação do conceito de carisma"2 (1991, p. 319). Daniel Bell, sociólogo responsável por popularizar o termo em um artigo de jornal em 1947, demonstrou arrependimento: "as pessoas não sabem o que significa. Os sociólogos não sabem o que significa” (LINGEMAN, 1968, p. 28). Alguns mais otimistas fazem um apelo epistemológico pela construção de uma visão unificada do conceito de carisma (MIYAHARA, 1983). As preces, no entanto, não surtiram efeito.

Ainda que não seja um problema que tire o sono dos sociólogos, o atual estado da arte do conceito de carisma é, na melhor das hipóteses, polissêmico, e, na pior, anárquico. A raiz disso pode estar na sua própria origem genética. Lindholm (2002) e Joosse (2014) apontam para a influência do Übermensch, de Friedrich Nietzsche. Nesse caso, o conceito de carisma teria sido desenvolvido a partir das análises históricas dos grandes homens do passado. A obra de Theodor Mommsen sobre os césares serve como uma evidência que apontaria para essa direção. Mas o mais provável - e aqui sigo muitos intérpretes (SCHLUCHTER, 1981; BENDIX, 1986; EISENSTADT, 1968; SELL, 2018) - é que as fontes sejam teológicas, mais especificamente o trabalho de Rudolf Sohm acerca do processo de estruturação do cristianismo. Seja César, seja Paulo, as raízes conceituais do carisma estão fundamentadas em lideranças pré-modernas, anteriores ao desencantamento do mundo e às tendências políticas e econômicas às quais a sociologia enfrentou ao se consolidar academicamente. $\mathrm{O}$ século $\mathrm{XX}$, apesar de suas turbulências sem precedentes, foi protagonista de um forte processo de democratização do ocidente, que ainda é mais regra que exceção. A sociologia não encontrou empecilhos para aplicar o conceito de carisma aos seus momentos autoritários e totalitários, como Adolf Hitler (LINDHOLM, 2002; LEPSIUS, 2007), Stálin (STRONG; KILLINGSWORTH, 2011) Fidel Castro (FAGAN, 1965) e Mao (SCHRAM, 1967), mas não teve o mesmo grau de eficácia e consenso em relação a líderes democráticos. De fato, Weber chegou a definir o carisma como "força

2 Em todos os casos em que a bibliografia citada está em outro idioma, a tradução é minha. 
revolucionária” (2000, p. 161), o que dificulta a sua aplicação para líderes políticos de sistemas altamente institucionalizados que exigem o cumprimento de normas e ritos. Contudo, o mesmo Weber (2000, p. 175-178) avaliou a possibilidade de um carisma antiautoritário. Além disso, interpretaçóes associando o conceito a populistas de regimes democráticos contemporâneos também já foram desenvolvidas (SELL, 2013). Mas qual é, portanto, a sua aplicabilidade para líderes democráticos que não subvertem a ordem institucional? Ou, aproveitando a deixa de Cavalli (1987), Kennedy foi, do ponto de vista sociológico, um líder carismático? E os casos brasileiros de Lula e Bolsonaro?

Assim, neste artigo, a partir de Weber, proponho a fundamentação de um conceito de dominação carismática que seja aplicável a uma sociologia política dos regimes democráticos, enfatizando que o caráter fundamental do carisma está na relação do dominador com os dominados. Não tenho a pretensão de retomar diretamente as polêmicas supramencionadas acerca de sua polissemia conceitual, nem, por óbvio, encerrar as disputas interpretativas que se formaram ao longo de um século. O desenvolvimento da minha argumentação se realizará em três pontos: 1) questóes preliminares relativas ao conceito weberiano de dominação e de carisma em seu tipo puro, sua rotinizaçâo e sua relação com a democracia plebiscitária; 2) apresentar uma definição de dominação carismática a partir da interpretação de Weber; 3) complementar a definição apresentada com consideraçóes que estão além da obra do sociólogo alemáo.

\section{A dominação carismática em Weber}

O ponto preliminar para a compreensão do pensamento de Weber acerca do carisma está na tripla divisão dos tipos de dominação criada pelo autor: racional-legal, tradicional e carismática. Os tipos de dominação estão entre os conceitos mais populares da sociologia weberiana. A dominação pode ser definida como uma relação social de obediência com pretensôes de legitimidade, i.e., ser reconhecida como tal. Nesses termos, a obediência é para Weber uma "máxima de conduta”, que deve ser acatada como uma ordem unicamente em virtude da relação social que a estabeleceu. 


\section{I O carisma em seu tipo puro}

A definição de carisma em tipo puro aparece da seguinte maneira:

Uma qualidade pessoal considerada extracotidiana (na origem, magicamente condicionada, no caso tanto dos profetas quanto dos sábios curandeiros ou jurídicos, chefes de caçadores e heróis de guerra) e em virtude da qual se atribuem a uma pessoa poderes extraordinários específicos ou então se a toma como envidada de Deus, como exemplar e, portanto, como "líder". (WEBER, 2000, p. 158-159).

A dominação carismática é, por consequência, a estrita obediência ao líder em virtude de seus poderes extraordinários. Como uma sociologia não valorativa, Weber não trata das qualidades éticas ou estéticas do compromisso criado a partir dessa relaçáo, nem da realidade objetiva dos poderes do líder, de sua mágica ou seu charlatanismo; na dominação carismática, há uma livre crença dos adeptos, incitada pelo líder através da relação social estabelecida.

O carisma e a tradição são os dois tipos usuais de dominação em épocas pré-racionalistas. Por essa razão, Weber aponta o carisma como um poder subversivo às dominaçóes tradicionais. O líder é uma força extracotidiana que desafia os costumes estabelecidos pela expressão de seus "milagres"; é por meio dos milagres que ele prova a sua vocação e estabelece a entrega dos dominados à sua revelação. A relação de dominação carismática, em seu sentido puro, é sempre dependente de novas provas e do bem-estar dos dominados. Por essa razão, trata-se de um tipo extracotidiano e instável de dominação, em oposição às outras duas formas elencadas por Weber, tipicamente cotidianas e estáveis. O líder deve provar "não apenas que Deus o enviou, mas que ele permanece do seu lado" (SCHLUCHTER, 1981, p. 121). Por falta de provas, a dominaçáo pode ser efêmera, e a vocaçáo do profeta pode se esvair tấo rapidamente quanto foi revelada ${ }^{3}$.

Pelo seu caráter subversivo, as crises sociais são as condições ideais para a conformação de uma liderança dessa natureza. É a situação em que o carisma alcança de maneira mais eficiente sua força transformadora, "nascida

3 O caráter possivelmente transitório e efêmero da dominação carismática na obra de Weber (2000, p. I6I) passa despercebido por muitos intérpretes que se focam apenas na sua "força revolucionária" e tomam "extracotidiano" como sinônimo de grandeza. 
da miséria ou entusiasmo", gerando uma nova conformação de crenças e açôes perante o mundo (WEBER, 2000, p. 161). Essa situação de crise torna o terreno propício à provação de novos líderes, podendo ser relacionada ao conceito de efervescência de Durkheim ${ }^{4}$ (1995) ou, de maneira mais precisa, à funçâo latente de Merton (1968). É pela segunda via que segue a análise de Lepsius (2007) sobre a ascensão carismática de Hitler. As crises geram condições latentes de inclinação social à crença na salvação e o líder carismático será aquele que melhor conseguir se apresentar como solução para o problema e for reconhecido como tal. Essa é a transição da potência latente para o ato. Seu sucesso vai depender de sucessivos testes vocacionais revelados em sua capacidade de dar prosseguimento à missão para a qual foi encarregado. Novamente, a qualidade do diagnóstico e da solução que o líder confere à crise náo é o objeto em discussão. Cada um pode construir seu próprio estratagema. Lepsius cita que Hitler agiu através da "dramatização da percepção da crise em direção à sua interpretação” (2007, p. 95). A metanoia, traço central de seu elemento subversivo, de maneira eficiente, representa a construção de uma relação de obediência a partir da modificação do sentido da consciência e das açóes dos dominados.

\subsection{Rotinização do carisma}

Se a dominação carismática não for uma relação efêmera, mas permanente, ela modifica o seu caráter, tradicionalizando-se ou racionalizando-se. O carisma tende a se institucionalizar, o que significa que ele não é um conceito meramente psicológico, pois produz estruturas típicas de dominação. Para utilizar a terminologia de Sell (2018), esse é o momento em que o poder subversivo do carisma se torna um poder instituido. O carisma, em seu tipo puro, é de caráter extraordinário - o que o torna incapaz de atuar cotidianamente. Essa mudança surge do interesse ideal ou material dos próprios adeptos; as missóes carismáticas são estranhas à família e à economia, mas não têm como se isolar permanentemente do mundo

4 É importante ressaltar que, apesar das aproximações, o sagrado de Durkheim não é o mesmo que carisma de Weber. A efervescência se consolida pela influência coletiva dos indivíduos, levando-os a um estado mental de frenesi e de arrebatamento por uma força superior onde o indivíduo já não age mais como agiria em situações ordinárias. "A intensidade e a repetição dessa experiência", afirma Weiss, "acabam por fixar a percepção quanto à existência desses dois mundos distintos" (2013, p. 175), um mundo mecânico e cotidiano; outro, sagrado e extraordinário. 
ordinário. Quando o cotidiano lhe toca a porta, torna-se necessário discutir questóes referentes a quadros administrativos e de sucessão do líder carismático. Diferentemente dos casos efêmeros, o carisma rotinizado acaba por se objetivar; afinal, ele se despersonaliza nas estruturas instituídas, em quadros administrativos, partidos e cargos, e também pode se hibridizar, abandonando sua forma pura, tornando-se um carisma tradicional ou racional.

A "tradicionalização" ocorre pela manutenção do poder do líder em razão dos interesses dos próprios adeptos. Os membros do séquito mais íntimo, antes uma mera escolha arbitrária de salvação, aos poucos se tornam seus senhores feudais, membros oficiais do Estado, secretários ou quaisquer outros cargos com suas respectivas distinçôes de acordo com a distribuição dos espólios do sucesso. O povo se torna súdito. "A relação entre o líder e seus seguidores", escreve Bendix, "[...] perde a fé em um poder ou uma missão extraordinários e passa a ter como base uma crença na autoridade santificada pela tradição" (1986, p. 241). A transição é possível porque ambos os tipos de dominação têm relação com o sagrado, ainda que de maneiras distintas. Todo apelo revolucionário de sua gênese se esvai, dando lugar às novas ordens sociais que fundou e cuja legitimidade brota do líder carismático que a instituiu. O carisma, portanto, é simultaneamente uma força destruidora e criadora de tradiçóes. Nesse sentido, após a rotinização, há obediência dos dominados ao líder carismático apenas na medida em que eles reconhecem a autoridade na santidade das tradiçóes fundadas pelo antigo líder. É, para a maior parte dos efeitos, uma dominação tradicional. Se essa mudança ocorre nos meios burocratizados do Estado ou em formas análogas de associação política, decorre-se a passagem para a sua versão racional e burocrática, quando, por exemplo, os antigos homens de confiança do líder se tornam funcionários do partido. A preocupação de Weber, segundo Gerth e Mills, não estava focada nas "grandes figuras" da história, mas em "[...] apreender o que se conservou do trabalho desses homens nas ordens institucionais”. Não se trata de Júlio César, mas o cesarismo; não Calvino, mas o calvinismo" (1974, p. 13).

A institucionalização do carisma gerou debates e atualizações na teoria sociológica, inclusive acerca de sua validade em sociedades seculares. 
Edward Shils (1965) desenvolve uma versão contemporânea da ideia de carisma institucional a partir do que denominou "necessidade de ordem", presente em qualquer vínculo social. A ordem aqui é simbólica e diz respeito ao centro da existência humana. $\mathrm{O}$ centro não é geográfico, mas uma conformação das principais crenças e instituiçóes que constroem a identidade dessa ordem. A suprema corte, o presidente, as casas legislativas, os juízes, os cientistas e até mesmo os cidadãos, todos gozam de algum prestígio carismático pela relação que a sua função exerce com o centro da ordem, enquanto o desprestígio é relativo à periferia, a distância que aquela função se encontra em relação ao centro. $\mathrm{O}$ carisma seria a própria razão da estratificação social - um ponto que ainda tem relação com Weber. Mas ela não se resume a uma relação de centro e periferia, pois "toda legitimação de um poder de larga escala contém um elemento carismático" (SHILS, 1965, p. 204). Segundo essa percepção, o carisma é parte essencial do poder instituído. Ele não é mais uma força extraordinária, é uma força arraigada ao cotidiano, dispersa em múltiplas funçôes.

A teoria de Shils é inteiramente institucional e pouco tem a dizer diretamente sobre lideranças. $\mathrm{O}$ carisma náo possui nenhum elemento revolucionário. $\mathrm{O}$ conceito perdeu o seu valor como principal fator de mudança social. A única via pela qual isso poderia ocorrer seria através de uma competição carismática entre o novo líder subversivo e as instituiçôes da ordem. Shils não desenvolveu tal questão, mas adentrando nas consequências lógicas de seu raciocínio, o sucesso do poder subversivo, em consonância com a tese de Weber, somente seria possível em uma situação de crise social, o que, nesse caso, seria o mesmo que uma crise de carisma institucional: o ruir do poder simbólico do centro diante da sublimação da periferia. A teoria passa a se distanciar da sociologia weberiana, no entanto, na medida em que o carisma é tratado como uma questão de identidade social. Em Weber, a rotinização ocorre do ponto de vista histórico a partir do momento em que o poder subversivo do líder se consolida como poder instituído e o carisma puro se rotiniza tradicional ou racionalmente. Para Shils (1965), contudo, se o carisma existe onde há poder; se a graça é concedida a tudo que se aproxima do centro simbólico, então ele é um fato social a-histórico. Como aponta Miyahara (1983), Shils acabou equalizando o conceito weberiano de carisma ao sagrado de Durkheim, provavelmente 
inspirado por Parsons (1947). Eisenstadt (1968) parece seguir pelo mesmo caminho. O sagrado, para Durkheim, sempre compreendido em dualidade com o profano, é "tudo aquilo que constitui objeto de adoração" (WEISS, 2013, p. 162), cujos poderes atribuídos se expressam através das lendas, dos mitos e das crenças. Em paralelo com a ordem de Shils, em uma sociedade constituída sob tal conformação, o líder teria de ser o "grupo encarnado e personificado" (DURKHEIM, 1995, p. 215), em oposição ao subversivo que a dominação carismática autoriza com mais facilidade.

\subsection{Democracia plebiscitária e burocracia}

É na relação estabelecida por Weber entre democracia e carisma que eu me aproximo de maneira mais enfática ao tópico principal do artigo. Nesse momento surge o senhor que Weber denominou "líder livremente eleito", também designado "carisma antiautoritário". Se parte significativa do que foi desenvolvido até aqui tem seus fundamentos e seus modelos exemplares em sociedades e lideranças pré-racionalistas, quando tratamos de democracia e eleição o tópico é simultaneamente mais familiar e mais moderno.

No carisma em seu tipo puro, a legitimidade de um líder é consequência do reconhecimento de sua autoridade por parte dos adeptos. $\mathrm{Na}$ legitimidade democrática; no entanto, há uma inversão: o reconhecimento é "considerado fundamento, em vez de consequência, da legitimidade". O reconhecimento é, no caso, a própria eleição. Trata-se de uma graça imanente concedida ao líder pelos dominados. As comunidades, antes inteiramente entranhadas à ideia de que havia apenas um único direto compatível com o dever, passam a reconhecer em si mesmas o poder de "declarar, reconhecer e revogar o direito", de maneira que "o tratamento do direito aproxima-se da concepção legal” (WEBER, 2000, p. 176). O princípio eletivo náo é aplicado exclusivamente aos líderes de grandes pretensôes. No modelo democrático, o quadro administrativo é formado por funcionários eleitos. Não são necessariamente quadros técnicos, nem burocráticos, nem impessoais; mas, assim como o líder plebiscitário, são figuras legitimadas em razão da confiança dos dominados. Creio que o resumo mais adequado para o conceito de democracia plebiscitária tenha sido escrito pelo próprio Weber: 
A “democracia plebiscitária” - o tipo mais importante da democracia de líderes -, em seu sentido genuíno, é uma espécie de dominação carismática oculta sob a forma de uma legitimidade derivada da vontade dos dominados e que só persiste em virtude desta. O líder (demagogo) domina, na verdade, devido à lealdade e à confiança de seu séquito político para com sua pessoa como tal. Ele domina, inicialmente, os partidários que conquistou e, em seguida, no caso de estes o levarem ao poder, toda a associação. (WEBER, 2000, p. 176).

É de interesse apontar que, apesar do caráter misto da dominação exercida nas democracias (como fica implícito em muitos pontos deste tópico), a relação entre o líder carismático e seus adeptos persiste assumindo a forma de uma ação que, por parte dos dominados, é afetiva ou emocional em relação à própria pessoa do líder. Ela já se caracteriza enquanto tal quando está restrita a um espectro de partidários e mesmo que o poder máximo da nação nunca seja alcançado. Para Weber, o caso exemplar deste modelo de democracia são os Estados Unidos da América.

Nesse contexto, Weber modifica os dois tipos de dominação antitéticos. A disputa privilegiada que tratamos anteriormente se dava entre tradição e carisma; logo, no âmbito democrático moderno, o nosso foco se concentrará na relação entre carisma e burocracia. Os Estados sofreram um processo de racionalização de quadros administrativos, com obrigaçôes objetivas, competências e salários fixos, qualificação profissional, disciplina, progressão de carreira e impessoalidade. Essa nova burocracia representa a cristalização do processo de racionalização do ocidente pelo exercício da dominação legal. "Num Estado moderno", escreve Weber, "[...] o verdadeiro governo, que não atua nos discursos parlamentares nem nos pronunciamentos dos monarcas, e sim no manejo da administração na vida cotidiana, está necessária e inevitavelmente nas mãos do funcionalismo" (2015a, p. 167). Afinal, cabe a esta classe decidir sobre todas as necessidades e reclamaçóes cotidianas da população. Embora a burocracia - dotada de racionalidade, impessoalidade e eficiência - seja necessária para o mundo moderno, Weber apresenta muitas desconfianças com relação à condução política que uma categoria com essas características viria a tomar.

A solução para o enrijecimento burocrático das democracias se encontra justamente nas lideranças políticas e no carisma como conceito antitético. Weber aponta uma diferença de fundamentos entre o político e o burocrata: a natureza de suas responsabilidades. Se um burocrata 
recebe uma ordem da qual discorda e, após ponderação, o superior insiste na ordem, ele deve cumpri-la como um dever ou uma honra, "como se correspondesse à sua própria convicção” (WEBER, 2015a, p. 180), sine ira et studio. Um político não pode agir dessa maneira. O burocrata, pela natureza de sua posição, deve estar acima dos partidos e fora da luta pelo poder. Por essa razão,

[...] a dominação dos funcionários falhou completamente sempre que teve de se ocupar de questões políticas. Isso não aconteceu por acaso. Seria, antes, surpreendente se capacidades intrinsecamente tão distintas coincidissem dentro da mesma estrutura política [...] não é próprio de um funcionário participar de conflitos políticos de acordo com suas convicções pessoais [...]. Pelo contrário, seu orgulho é proteger sua imparcialidade e, portanto, poder superar suas próprias inclinações e opiniões. (WEBER, 2015a, p. 195).

Weber não está negando a necessidade ou a utilidade da burocracia no mundo moderno, mas afirmando que, por muito tempo - especialmente na Alemanha -, ela esteve exercendo uma função que não lhe é própria, com responsabilidades que desconhece e com vocaçóes que lhe são estranhas. Dessa forma, o sociólogo conclui que "os políticos devem ser o contrapeso à dominação do funcionalismo” (WEBER, 2015a, p. 196). Ou seja, a política, o carisma e a ação afetiva ou emocional na defesa ativa de suas causas são maneiras de balancear o racionalismo e a impessoalidade técnica do burocratismo. Assim a simpatia por uma ordem mais carismática se consolidou no pensamento de Weber, percebendo que "o carisma não era apenas um fenômeno sociológico inusitado", aponta Adair-Toteff (2015, p. 153): "mas que o líder carismático provavelmente era a melhor escolha para o futuro político".

Tal crença deve ser sopesada. Se Weber acreditava que o líder carismático era a melhor opção política para o futuro, temos duas opções para interpretar seu pensamento: ou Weber era antidemocrático, ou ele acreditava que era possível balancear democracia e dominação carismática. Os trechos supramencionados de sua obra dão um bom indicativo de que a segunda resposta é a correta. Então encontramos outro problema. Se a dominação carismática for exclusivamente revolucionária, antissistêmica e contrária à ordem estabelecida, a teoria de Weber, ao permitir a conciliação entre as duas coisas, acabaria fatalmente levando à conclusão de que a demo- 
cracia é um regime implosivo cujo destino é parir o seu próprio carrasco. Esse desfecho, no entanto, não está presente em seus livros. Mesmo em O Presidente do Reich, um dos textos mais pró-carisma de Weber, fica claro que o líder deve ser constrangido por normas institucionais. "Devemos cuidar", ele escreve, "[...] para que o presidente do Reich sempre tenha perante os olhos 'forca e corda' como consequência de qualquer tentativa de interferir nas leis ou de governar autocraticamente" (WEBER, 2015b, p. 310). Deve-se "limitar o poder do presidente eleito pelo povo" e permitir a sua interferência apenas em casos "[...] de crises temporariamente insolúveis (mediante o veto suspensivo e convocação de ministros compostos de funcionários públicos)" (WEBER, 2015b, p. 312). Mesmo sua força revolucionária não foi descrita como absoluta, ele apenas afirmou que o carisma tinha essa característica em "épocas com forte vinculação à tradição" (WEBER, 2000, p. 161). A exegese de Weber, portanto, permite claramente uma interpretação que concilie democracia e dominação carismática em uma versão antiautoritária.

\section{Definindo a dominação carismática}

A interpretaçáo do conceito de dominação carismática que pretendo contrapor neste artigo é apresentada por Lepsius em seu célebre estudo sobre o nazismo - ainda que seja uma posição bem difundida, é mais brilhantemente apresentada por ele ${ }^{5}$. Lepsius argumenta que enquanto um líder "não muda o sistema social", ou não excede às expectativas do cargo que assumiu, ele "não pode ser um líder carismático" (LEPSIUS, 2007, p. 92). John F. Kennedy, Marthin Luter King e Otto Von Bismarck são apresentados como líderes "carismatizados", não propriamente líderes carismáticos; em outras palavras, não cumpriram os requisitos básicos do conceito, não romperam com a ordem estabelecida. Embora náo se possa afirmar, mesmo com essa definição, que apenas tiranos sejam dignos de tal denominação, a conexão do conceito com líderes democráticos que seguem a ordem institucional tende a ser frágil. No que segue apresentarei uma posiçáo contrária à de Lepsius, defendendo que a chave para a

5 Por exemplo, Adair-Totteff (2015), Bendix (1986), Kalyvas (2008) e Pappas (201 I) apresentam visões semelhantes. 
compreensão da dominação carismática está na relação social estabelecida entre o líder e o dominado, não nas consequências do ato do líder. As questôes básicas da sociologia de Weber apresentadas até aqui servirão como auxílio para fundamentar minha posição.

Sendo a dominação carismática interpretada, conforme exposto anteriormente, como a obediência de um seguidor a um líder em virtude de seus poderes extraordinários, e sendo a obediência compreendida como uma máxima de conduta, o axioma básico do conceito se encontra na relação de dominação exercida entre os agentes. Existe um relacionamento recíproco na medida em que um age em referência ao outro, mas a reciprocidade referencial não se traduz em reciprocidade de sentido: náo se trata de uma relação mútua de obediência, trata-se de uma relação em que um ordena e o outro obedece. Até este ponto qualquer tipo de dominação é aplicável. O diferencial da dominação carismática está em uma das formas de legitimidade citadas por Weber: "[...] a legitimidade de uma ordem pode estar garantida: [...] 1. de modo afetivo: por entrega sentimental" (2000, p. 20). A ação tipicamente relacionada ao carisma é, portanto, a ação afetiva ou emocional, que busca a satisfação de uma necessidade atual de maneira inconsequente e não planejada. Os termos costumeiramente empregados por Weber para definir o reconhecimento da legitimidade do líder por parte dos adeptos são tipicamente psicológicos: "entrega crente", "entusiasmo", "miséria” ou "esperança”. Dessa maneira, em seu sentido mais básico, caracteriza-se dominação carismática toda relação de dominação cuja raiz da obediência de um adepto a um lider seja o vinculo afetivo e a entrega emocional do adepto em razão dos poderes extraordinários ou do caráter exemplar do líder. Essa é uma definição suficientemente abrangente para possuir uma aplicabilidade razoável aos regimes democráticos sem perder o conteúdo explicativo do conceito e, também, sem ignorar a possibilidade de seu caráter revolucionário. A partir da amplificação dessas relaçóes se funda uma coletivização emocional desses vínculos gerando grupos que gravitam sobre um mesmo líder.

Esse caráter emocional é demonstrado de diversas formas em estudos sobre líderes carismáticos. Era comum entre apoiadores de Fidel Castro, como demonstra Fagan (1965), expressar que o beijariam ou que morre- 
riam junto com ele. A comparação do líder da Revolução Cubana com o divino também aparece entre seus fiéis, os quais afirmam coisas como: "Fidel Castro é um instrumento das mãos de Deus para o estabelecimento de Seu reino entre os homens"; "Fidel tem as mesmas ideias que Jesus Cristo, nosso protetor e guia" (FAGAN, 1965, p. 278). Andrews-Lee aponta como "as emoçôes profundamente guardadas" e "as memórias alegres" mantiveram o vínculo dos cidadãos venezuelanos com o bolivarianismo "apesar da morte de Chávez e das circunstâncias desfavoráveis” (2020a, p. 20). Acerca de poderes extraordinários, Mao era considerado o "mediador entre o povo chinês e o seu destino histórico" (SCHRAM, 1967, p. 387). Khomeini, de acordo com Ashraf, era para os seus seguidores "[...] o redentor e a esperança para os miseráveis da Terra e para os milhóes que ainda vivem em uma 'Era de Crença”" (1990, p. 142). Esses são apenas alguns exemplos. $\mathrm{O}$ caráter emotivo, cuja miséria e entusiasmo se fazem presentes nos trechos supracitados, possui um vínculo de reciprocidade e de retroalimentação com as suas características extraordinárias; nesses casos extremos, o amor é produto do contato com o divino.

Transformar o afetivo no ponto central do conceito não é uma novidade. No entanto, deve-se manter o cuidado de não outorgar à dominação carismática uma definição excessivamente psicológica ${ }^{6}$. A interpretação psicanalítica de Camic (1980), além de conferir ao conceito elementos patológicos, iguala o carisma a um objeto de adoração afetiva a partir de necessidades individuais extraordinárias. Como Miyahara (1983) aponta, se um sujeito esquizofrênico desenvolve uma veneração por uma boneca qualquer, essa relação pode ser incluída, sob a concepção de Camic, como uma dominação carismática. Do ponto de vista sociológico isso é inócuo, e o mesmo reducionismo individualizante não pode ser empregado para a definição que estabeleci anteriormente. A base do conceito é a relação social da dominação carismática. Para Weber, isso significa que há pelo menos dois agentes na equação. Uma boneca pode ser objeto de adoração como um símbolo sagrado, e, na medida em que isso se torna um fenômeno

6 Estou me referindo ao interesse sociológico deste trabalho. Isso não significa que não possa haver nenhuma reflexão psicológica acerca do fenômeno nem que a psicologia não pode, de forma geral, se propor a estudar as razões psíquicas dessa relação. 
social, pode ser estudado sociologicamente. No entanto, uma boneca é incapaz de realizar uma açáo de qualquer natureza; consequentemente, não se trata de dominação carismática, mas de outro tipo de fenômeno. As mesmas considerações explicam por que o carisma não se iguala efetivamente ao sagrado. Afastando-se de sua versão psicanalítica, o conceito de dominação carismática pode tratar tanto do indivíduo - apresentando-o como um retrato microcósmico do macrocosmo social - quanto de aspectos macrossociais da ação do líder - os quais se refletem nas estruturas e nas instituiçóes políticas.

$\mathrm{Na}$ mesma linha argumentativa, faz-se necessário distinguir a posição de Weber daquelas apresentadas por Gustav Le Bon (1963) e Gabriel Tarde (1890) quanto às "situaçôes de massa". Algumas reaçóes podem ser facilitadas ou dificultadas pelo simples fato de um indivíduo fazer parte de um grupo. Contudo, a situação de massa de Le Bon se refere a uma ocorrência potencialmente hipnótica e puramente reativa. Para Weber, esse tipo de acontecimento sequer poderia ser considerado uma ação, pois não possui relação de sentido. Igualmente, a imitação de Tarde, que faz constantes analogias a situaçóes hipnóticas e a sonhos, "[...] não pode ser considerada uma ação especificamente 'social' quando é puramente reativa, sem orientação da ação própria pela alheia quanto ao sentido" (WEBER, 2000, p. 14). Dessa maneira, numa relação de dominação carismática, ainda que os adeptos estejam mobilizados por uma ação afetiva, que está, segundo Weber, no limite "daquilo que é uma ação conscientemente orientada" (WEBER, 2000, p. 15), as suas açóes possuem um sentido subjetivamente visado - não se encontram, portanto, em uma situação descerebrada, hipnótica ou animalesca. Com isso, não estou afirmando que situaçóes de massa à maneira de Le Bon simplesmente não existam - o que caberia um estudo de outra natureza -, mas que a dominação carismática não é caracterizada como tal, ainda que muitas semelhanças entre as duas teorias possam ser apontadas sem erros ${ }^{7}$. A transição de uma ação puramente rea-

7 O próprio Weber é responsável por algumas aproximações ao tratar do conceito de demagogia. Em Parlamento e Governo, ele afirma que "a massa", como a experiência demonstra, pensa apenas até "depois de amanhã" e "sempre está exposta à influência atual, puramente emocional e irracional" (2015a, p. 242). Dessa forma, poder-se-ia deixar em aberto a possibilidade de situações extremas que aproximariam Weber das concepções de Le Bon e Tarde. 
tiva para uma dotada de sentido é bastante fluida, como Weber gosta de ponderar, talvez até sociologicamente imperceptível. Mas claramente não há uma continuidade lógica e conceitual direta entre os três pensadores, como acredita Lindholm (2002).

\section{Intensidade, difusão e direção do carisma}

Excluídas algumas interpretações e comparações incabíveis, passo agora a ponderações sequenciais da definição de dominação carismática. Desse ponto em diante, não trato mais de uma exegese direta de Weber, mas de possíveis desenvolvimentos da teoria a partir do que foi estabelecido pelo sociólogo alemão.

Em seu estudo, Lepsius (2007, p. 92) aponta que a interpretação weberiana permite discriminar o carisma em intensidade e direção. A minha contribuição é semelhante, mas com algumas importantes modificações. $\mathrm{Na}$ concepçáo de Lepsius, a intensidade é a força da relação carismática, o problema é que essa força é medida na proporção do abandono das normas políticas institucionalizadas. Embora exista correlação entre as duas coisas, essa não precisa ser a única régua. De fato, a intensidade deve medir a força da obediência, mas ela não precisa ser uma obediência revolucionária. O que vai indicar o teor normativo da obediência é justamente a sua direção, que é, nos termos weberianos, o sentido da ação, ou em uma concepção mais familiar à filosofia da linguagem contemporânea, a intenção. Eu acrescentaria, ainda, um terceiro elemento: a difusão do carisma, estritamente ligado ao número de adeptos. Intensidade e difusão não possuem o mesmo significado. É possível que um líder possua alto grau de carisma com baixa difusão, e vice-versa. Com isso, não pretendo quantificar as relações de dominação carismática a partir de três variáveis, mas apenas ponderar três aspectos ideais-típicos de sua natureza. Em especial o caso da direção, intimamente relacionado aos interesses e valores do lider, possui fundamental importância para uma interpretação democrática do carisma, pois são os interesses que o líder possui pelas regras democráticas, ou até mesmo os valores que prezam por essas mesmas instituiçóes, que são capazes de manter um líder carismático dentro das relaçôes institucionais ordinárias - ainda que o grau e a difusão de seu carisma sejam extraordinários. Podemos listar os itens da seguinte forma: 
Quadro I - Dimensões da Dominação Carismática

\begin{tabular}{|l|c|}
\hline Intensidade & Propriedades qualitativas da relação carismática \\
\hline Difusão & Propriedades quantitativas da relação carismática \\
\hline Direção & Sentido ou intenção do líder carismático \\
\hline
\end{tabular}

Fonte: Elaborado pelo autor (2020).

É possível que um político consiga, por meio de seu carisma, mobilizar um grande número de seguidores para defendê-lo, por exemplo, de uma acusação bem fundamentada de corrupção, mas que seja incapaz de se fazer obedecer diante de ordens mais radicais, caracterizando alta difusáo e baixa intensidade. Essa talvez seja a variante mais comum de líderes populares carismáticos em democracias contemporâneas, especialmente aqueles que não conseguem (ou não tentam) romper com a ordem institucional ${ }^{8}$. De modo inversamente proporcional, alguns séquitos são capazes de seguir o líder até a morte - literalmente -, como no caso do suicídio coletivo da seita de Jim Jones (JOHNSON, 1979), cuja relação carismática possuía alta intensidade, mas com uma difusão muito reduzida. Igualmente possível, mas mais rara, é a possibilidade de um político conquistar, simultaneamente, alta difusão e intensidade. Nesse caso, os estudos de Lepsius (2007) sobre a ascensão de Hitler servem como exemplo. Em outra direção, também é o caso de Jesus (PIOVANELLI, 2005): 2 mil anos após a sua morte, sua palavra continua sendo ouvida, difundida e obedecida - por vezes com muita intensidade - por um percentual muito significativo não apenas de uma nação, mas de toda a humanidade. Contudo, provavelmente os casos mais comuns e menos estudados dizem respeito aos carismas efêmeros, de baixo ou médio alcance em todos os critérios. Podemos citar figuras políticas que possuem um público muito específico, geograficamente loca-

8 Podemos aqui levantar a hipótese do quanto líderes contemporâneos de sistemas representativos como Obama, Lula, Trump e Bolsonaro poderiam se encaixar, com direções distintas, nessa categoria: todos possuem um percentual não desprezivel de seguidores emocionalmente engajados que não raramente lhes atribuem qualidades extraordinárias. A confirmação dessa hipótese dependeria de um estudo específico para cada caso, o que foge do escopo deste artigo, mas algumas qualidades carismáticas dos políticos citados já foram trabalhadas em algumas pesquisas (BOWDEN, 20I0; SAMUELS; ZUCCO JR., 20I4; JOOSSE, 20I8a, 20I8b; CESARINO, 2019). 
lizado, ou líderes comunitários e religiosos, desde que eles consigam, ainda que por momentos mais breves, construir uma relação de dominação com seus seguidores cuja obediência esteja atrelada a um vínculo afetivo e a um pretenso caráter extraordinário.

É importante ressaltar, no entanto, que uma aplicação para o conceito em um contexto democrático não significa igualar o líder carismático a qualquer outro conquistador de votos. Um líder comum pode se estabelecer por suprir de maneira mais eficiente os interesses da população, por representar os valores de determinada localidade, classe ou grupo, ou simplesmente pela construção de um marketing preciso. Essas são, na verdade, as relaçóes políticas mais usuais. Nada disso configura uma relação afetiva de obediência. Essa diferenciação também não indica qual líder será mais popular, pois interesses e valores - que geram diferentes estratégias e retóricas - podem ser tão ou mais eficazes que os afetos. É mais provável que em um contexto eleitoral alguns líderes possuam eleitores de todos os tipos: interessados, ideológicos e fiéis, com variaçôes de intensidade e difusão ${ }^{\text {. }}$ Nos conceitos sociológicos fundamentais, Weber aponta que a transição da ação racional com relação a valores para a ação afetiva é fluida. Em alguma medida, essa afetividade pode se transferir para o candidato que representa esses valores. Pode-se imaginar que o contexto eleitoral, ocasiāo de grande efervescência política, seja um desses momentos em que a distinção ideal-típica fique enodoada e a relação se torne mista. Ainda assim, deve-se pontuar que a simples manifestação emocional dos valores e dos interesses não caracteriza uma dominação carismática se ela não for suficiente para gerar obediência ao líder em razão de seu caráter exemplar ou extraordinário, reforçando que a origem do carisma sempre deve ser personalista ${ }^{10}$.

9 Pappas (20II) elenca alguns "sintomas" da existência da dominação carismática em sistemas representativos: I) a quase absoluta centralização exercida por um único líder em um partido ou movimento de massa; II) a grande e irrazoável paixão que acompanha a relação entre o líder e os seguidores; III) a capacidade missionária e delegativa do líder diante dos fiéis. Apesar de a definição de Pappas estar mais diretamente ligada ao carisma autoritário, essas características não são contraditórias com a definição aqui apresentada.

I0 O carisma institucional disperso e despersonalizado, em conformidade com a posição de Shils, é uma hipótese plausível apenas na medida em que os indivíduos possam prestar obediência a determinadas instituições pela relação afetiva que construíram com elas. Um grande apego afetivo à ordem democrática, por exemplo, pode gerar uma dominação mista, simultaneamente racional-legal e carismática, em que a obediência a uma ordem legal de um juiz (aqui se caracteriza a relação social) se consolide mais pela dedicação emocional à ordem política instituída do que pela sua legitimidade racional. Deve-se tomar com cautela essa hipótese, tratando-a como 
A direção determinará a relação dos adeptos com as instituiçôes. A dominação carismática pode ser mobilizada para a realização de mudanças radicais na ordem estabelecida, tanto na direção "progressista" quando na direção "reacionária". A primeira é a demonstração revolucionária, afeita à missão e às promessas de prosperidade e bem-estar por parte do líder que se realizariam hipoteticamente em uma nova ordem construída sobre as ruínas do status quo. A versão reacionária, menos trabalhada sociologicamente, de caráter misto, ocorre quando o carisma mobiliza a tradiçấo para a refundação de uma nostálgica e finada era sociopolítica. É o caso da Revolução Iraniana e seu líder Khomeini, com fortes traços de dominação carismática (ASHRAF, 1990; BRUMBERG, 1997). Diferentemente do que argumenta Levay (2009), esse tipo de uso do carisma não foge ao conceito weberiano. Ainda que o poder subversivo esteja atrelado a uma força tradicionalista e que o fundamento de sua promessa resida no retorno ao passado, não há de fato um retorno; o sucesso do projeto leva à conformação de uma ordem política tradicionalmente orientada, mas ainda uma nova ordem, mesmo que neofóbica. Menos desenvolvida que ambas as concepções anteriores é a dominação carismática exercida por forças ligadas, de alguma forma, ao status $q u o$ - especificamente nos casos democráticos. A obediência afetiva ao líder pode ser direcionada para estratégias que não rompam com as instituiçóes democráticas. Ela pode ocorrer: a) para a simples consolidação eleitoral de uma nova elite política, constituída pela graça do líder; b) para o reformismo social "progressista", também caracterizada por uma missão de mudança, mas evitando o rompimento com as regras do jogo democrático; c) para o reformismo reacionário, cuja missão de reestabelecimento dos antigos valores se efetue institucionalmente. Os carismas " $b$ " e " $c$ " não são necessariamente contraditórios a " $a$ ".

Pode acontecer de um carisma autoritário surgir em um contexto democrático. Nesse caso, o líder sempre agirá no limiar das normas

uma probabilidade menor. De qualquer maneira, o carisma institucional não pode ser atribuído a representantes individuais das instituições, como sugere Shils (1965, p. 206). A raiz da dominação por parte do adepto sempre deve se encontrar, nessa hipótese, em sua relação afetiva com as instituições, não com o indivíduo que ocupa o cargo - a propriedade carismática não está na pessoa, mas nas regras. Os cargos próximos ao "centro da ordem" exercem dominação carismática individualmente apenas na medida em que suas relações estabelecidas de obediência afetiva são de liderança pessoal, nunca por dispersão burocrática, assim retornando ao cerne personalista do conceito. 
institucionais e poderá, de acordo com a oportunidade, tentar um golpe contra o regime" ${ }^{\prime}$. Embora essa seja uma consequência direta da direção da relação de dominação, o vínculo carismático já está estabelecido quando a relação se consolida, sem necessitar da concretização das vontades autoritárias. A dominação carismática não existe em razão da consolidação das intenções do agente ou das consequências intencionais da ação, mas já na própria configuração de uma relação de obediência afetiva em razão das características extraordinárias do líder, ainda que a latência nunca se torne potência.

Em todos os casos democráticos, a dominação carismática e a legitimidade não se concretizam em seus tipos puros. Sua íntima relação com as instituiçốes democráticas lhe confere um caráter misto proveniente da racionalidade legal. Se por um lado a legitimidade do líder em relação aos seus adeptos reside na dominação carismática, a crença na legitimidade do mesmo líder em relação à totalidade do Estado-nação - incluindo opositores ou eleitores náo carismaticamente dominados - se baseia no direito impessoal de mando daqueles que estão nomeados a determinadas posiçóes da ordem instituída em concordância com os procedimentos legais. O tipo específico de dominação depende de quem está obedecendo.

A mistura dos tipos-ideais weberianos não possui como consequência a eliminação de todas as outras características proféticas, mágicas ou revolucionárias da dominação carismática em contextos democráticos. Como demonstra Lepsius (2007), o líder busca dramatizar a percepção ideológica dos adeptos através de construçóes maniqueístas, duais e restritas da realidade política, não raramente apelando a conspiracionismos, às emoçôes, ou, em alguns casos, ao radical recorro político da relação amigo-inimigo - ainda que, em ocasióes democráticas, tal mobilização seja mais problemática. A dramatização constrói a base de valores abstratos do séquito de seguidores. Consolidada a relação carismática, a partir de certa intensidade de dominação o líder busca possuir o monopólio da interpretação ideológica dos adeptos. Os fiéis, portanto, passam a ler a realidade pela ótica do líder. O sentido da ação social do séquito tende a emular o sentido da ação do

I I Uma direção oposta na ação social também é possível: a criação de um carisma democrático que se manifeste em regimes autoritários, como no caso de Atatürk (RUSTOW, 1968). 
salvador. Há diversas maneiras de mobilizar esse poder. Por intermédio do carisma antiautoritário, o líder pode buscar engajamento dos seguidores para as suas pautas econômicas, para a consolidação de políticas públicas e projetos de reformas do Estado, mas se mantendo restrito às vias institucionais legítimas. Em sua versão autoritária, o mesmo tipo de engajamento pode acontecer mediante ameaças aos outros poderes do Estado, por medidas ilegítimas ou até mesmo pelo recurso à violência política. Do ponto de vista individual, outros comportamentos dos seguidores podem ser explicados em razão da força da ação do dominador: a defesa incondicional do líder, mesmo diante de fortes acusaçôes morais e políticas; a aceitação passiva de leituras flagrantemente contraditórias de seu próprio ideário político, social e econômico; a crença em conspiraçóes irreais ou altamente improváveis, carentes de provas, que supostamente existam contra o líder; ou até mesmo a crença em notícias incontestavelmente falsas que, de alguma maneira, beneficiam o líder ou prejudicam o adversário. A lista poderia se estender a todas as açóes realizadas pelos adeptos em razáo da obediência à interpretação ideológica do líder, esta que, nesse caso específico, ocorre em coexistência com os regimes democráticos.

O vínculo eleitoral de uma relação carismática também se diferencia dos casos ordinários. Quando o eleitor está comprando o "produto" eleitoral do líder - para utilizar a famosa imagem de Schumpeter -, ele não está adquirindo apenas um pacote de promessas de políticas públicas, mas um completo filtro moral e político que será mobilizado para ler a realidade, as notícias, e, igualmente, para moldar a sua ação. $\mathrm{O}$ seguidor passará a encarar os fatos a partir das declaraçóes e das narrativas oficiais do profeta, privilegiando aquilo que beneficia o chefe com o qual está emocionalmente comprometido ou que prejudique os adversários. $\mathrm{O}$ grau em que isso acontece depende da intensidade da relação carismática. Esse amplo espectro de açôes defensivas e ofensivas está diretamente ligado ao caráter extraordinário que o seguidor atribui ao seu profeta, que não pode, em razão de sua santidade, estar envolvido em um esquema de corrupção; não pode estar se contradizendo ou descumprindo promessas; não pode estar no centro de polêmicas ou cometer erros, senão por uma conspiração 
obscura; e não pode estar transmitindo uma informação falsa. Nos casos mais intensos, pela afetividade da relação social, a reação do fiel às acusaçôes tenderá a ser emotiva, negatória e até mesmo violenta ${ }^{12}$.

No mundo contemporâneo, em que as redes sociais adquiriram importância política, novos meios podem ser mobilizados para estreitar os vínculos afetivos de dominação, a partir de uma relação "face a face" virtual. $\mathrm{O}$ mundo digital também permite a criação de mecanismos tanto de informação quanto de desinformação mais eficientes. A mensagem do líder, seja incitando uma ordem, seja comunicando uma narrativa oficial, pode ser transmitida com mais rapidez a distâncias maiores. Isso levou Toode a concluir, estudando casos da Itália e da Estônia, que "líderes políticos carismáticos podem ser mais bem-sucedidos no novo ambiente midiático" (2020, p. 21). Podemos até refletir sobre o quanto o anonimato virtual pode gerar uma amplificaçáo do fanatismo por facilitar ataques a adversários políticos sem qualquer consequência de exposição pessoal, social ou jurídica. Mesmo que algumas dessas consideraçóes sejam especulativas, já existem estudos sobre as açôes de líderes carismáticos em redes sociais (CESARINO, 2019; TOODE, 2020). Sem dúvidas, muitos dos expedientes citados são pouco republicanos e podem ser contrastados ou atenuados pela burocracia e pelas instituiçôes políticas e judiciais na medida em que alcançam ou ultrapassam os limites democráticos. Mas essas açóes não apenas coexistem com a democracia contemporânea como também fazem parte das estratégias eleitorais, políticas e comunicacionais de muitos de seus líderes.

\section{Considerações finais}

O conceito de carisma sempre foi facilmente aplicado a contextos políticos revolucionários como poder subversivo e, posteriormente, poder instituído; no entanto, com frágil funcionalidade para os regimes de-

12 O que constitui uma das bases primevas da distinção entre um indivíduo que segue um líder por razões carismáticas e um que o faz por interesse ou valor. Este último grupo não possuirá uma reação emocional às acusações e não terá dificuldade em abandonar o líder quando ele não satisfizer mais seus interesses ou os valores que, em primeiro lugar, eram a razão pela qual o vínculo foi criado. 
mocráticos contemporâneos. Durante o artigo busquei demonstrar que é possível, partindo de Weber, desenvolver uma interpretação do conceito de dominação carismática que seja aplicável a líderes que não fujam das rédeas institucionais ordinárias, usando como axioma básico a relação afetiva ou emocional de dominação estabelecida entre o líder e o dominado. Essa condição - que, em âmbitos democráticos, é sempre um misto de dominação carismática e dominação racional-legal - é gerada a partir da obediência dos adeptos, os quais se resguardam às ordens do detentor do carisma como máximas ou à sua interpretação ideológica dos fatos políticos e sociais.

Dessa maneira, o conceito de dominação carismática, quando desenvolvido a partir de relaçóes afetivas de obediência, pode ser aplicável tanto ao seu caráter revolucionário comumente mobilizado na bibliografia sociológica, quanto como uma explicação plausível para determinas relações de dominação estabelecidas entre líderes e adeptos em sociedades políticas democráticas. Novas pesquisas podem ser desenvolvidas a partir dessa relação para corroborar ou descartar algumas hipóteses levantadas. No âmbito macropolítico, essa perspectiva pode ajudar a explicar a fundação, capitalização, consolidação e rotinização da dominação carismática de líderes políticos que atuam em sistema democráticos, tendo como foco a relação social de base emotiva estabelecida entre o dominador e os seguidores. Disputas por sucessão e pela herança do carisma do líder também foram apenas brevemente mencionadas, mas representam um campo frutífero de pesquisa ${ }^{13}$. $\mathrm{Na}$ dimensão micro, pode-se buscar compreender alguns comportamentos dos dominados, tais como: a mobilização emocional em defesa de líderes políticos, a transição de parte da opiniâo pública acerca de alguma reforma em conformidade com a defesa do líder, a crença em obscuras teorias da conspiração, a aceitação acrítica - e consequente propagação - de notícias falsas e a incredulidade diante de acusaçóes jurídicas e políticas. $\mathrm{Ou}$ seja, a partir de um filtro ideológico "recebido" do dominador que busca

I3 A herança do carisma já foi discutida nos casos de Stálin (STRONG; KILLINGSWORTH, 20II), Khomeini (BRUMBERG, 1997) e de movimentos latino-americanos como o chavismo, o peronismo e o fujimorismo (ANDREWS-LEE, 2020b). 
engajar comportamentos e crenças que privilegiam o líder. O caráter mais ou menos democrático de todos esses elementos depende da direção das ações do político e de seus seguidores.

Nas sociedades democráticas modernas, é comum a coexistência de determinada intensidade e difusão de carisma com a dominação racional-legal rotineira. O método político utilizado, a partir de eleiçôes livres e periódicas, estimula concursos de popularidade e encantamento - mesmo que provisórios e efêmeros -, gerando um ambiente propício à consolidação de relaçóes de natureza carismática. Esses concursos eleitorais podem se pautar em valores e interesses, mas náo é raro o apelo à paixão, ao ódio, à raiva, ao medo e outros aspectos da psicologia social que podem favorecer o estabelecimento de vínculos carismáticos. Sell aponta que “[...] tanto em sua origem quanto em sua modalidade presidencialista, a democracia é um fenômeno cujo núcleo é essencialmente carismático" (2018, p. 10). A desmagificação e a secularização do mundo não impediram o surgimento de fenômenos que buscam reencantar a vida política, aflorando paixóes e relaçóes personalistas de dominação. A democracia é a arena em que algumas dessas faíscas mágicas do passado sobreviveram à racionalização do mundo moderno.

\section{Referências}

ADAIR-TOTEFF, Christopher. Fundamental Concepts in Max Weber's Sociology of Religion. London: Palgrave McMillan, 2013.

ANDREWS-LEE, Caitlin. The Power of Charisma: Investigating the Neglected Citizen-Politician Linkage. Journal of Politics in Latin America, v. 11, n. 3, p. 298-322, 2020a.

ANDREWS-LEE, Caitlin. The Politics of Succession in Charismatic Movements: Routinization versus Revival in Argentina, Venezuela, and Peru. Comparative Politics, v. 52, n. 2, p. 289-316, 2020 b.

ASHRAF, Ahmad. Theocracy and Charisma: New Men of Power in Iran, International Journal of Politics, Culture, and Society, v. 4, n. 1, p. 113-152, 1990.

BENDIX, Reinhard. Max Weber: um perfil intelectual. Brasília: Editora Universidade de Brasília, 1986. BOWDEN, Gary. Obama, Palin and Weber: Charisma and Social Change in the 2008 U.S. Election. Canadian Review of Sociology, v. 47, n. 2, p. 171-190, 2010.

BRUMBERG, Daniel. Reinventing Khomeini: the struggle for reform in Iran. Chicago: Chicago University Press, 1997. 
CAVALLI, Luciano. Charisma and Twentieth-Century Politics. In: WHIMSTER, Sam; LASH, Scott (org.). Max Weber, Rationality and Modernity. New York: Routledge, 1987. p. 317-333.

CAMIC, Charles. Charisma: Its varieties, preconditions, and consequences. Sociological Inquiry, v. 50, p. 5-23, 1980.

CESARINO, Letícia. Identidade e Representação no Bolsonarismo. Revista de Antropologia, v. 63 , n. 3, p. $530-57,2019$.

CESARINO, Letícia. Como vencer uma eleição sem sair de casa: a ascensão do populismo digital no Brasil. Internet \& Sociedade, v. 1, n. 1, p. 91-120, 2020.

DURKHEIM, Émile. Formas Elementares da Vida Religiosa. São Paulo: Martins Fontes, 1995.

EISENSTADT, Shmuel Noah. Introduction. In: WEBER, Max. Max Weber: On Charisma and Institution Building. Chicago: University of Chicago Press, 1968. p. IX-LVI.

FAGAN, Richard R. Charismatic Authority and the Leadership of Fidel Castro. Western Political Quarterly, v. 18, p. 275-284, 1965.

GERTH, Hans Gerth; MILLS, C. Wright. Introdução: o homem e sua obra. In: WEBER, Max. Ensaios de Sociologia. Rio de Janeiro: LTC - Livros Técnicos e Científicos Editora S.A., 1982. p. $15-93$.

JOHNSON, Doyle Paul. Dilemmas of Charismatic Leadership: The Case of the People's Temple. Sociological Analysis, v. 40, n. 4, p. 315-323, 1979.

JOOSSE, Paul. Becoming a God: Max Weber and social construction of charisma. Journal of Classical Sociology, v. 14, p. 266-283, 2014.

JOOSSE, Paul. Countering Trump: Toward a Theory of Charismatic Counter-Roles. Social Forces, v. 97, n. 2, p.1-14, 2018a.

JOOSSE, Paul. Expanding Moral Panic Theory to Include the Agency of Charismatic Enterpreneurs. The British Journal of Criminology, v. 58, n. 4, p. 993-1012, 2018b.

KALYVAS, Andreas. Democracy and the Politics of the Extraordinary: Max Weber, Carl Schmitt, and Hannah Arendt. New York: Cambridge University Press, 2008.

LE BON, Gustave. Psychologie des Foules. Paris: Les Presses Universitaires de France, 1963.

LEPSIUS, Mario Rainer. Max Weber and Institutional Theory. Switzerland: Springer, 2017.

LEVAY, Charlotta. Charismatic leadership in resistance to change. The Leadership Quarterly, n. 21, p. 127-143, 2010.

LINDHOLM, Charles. Charisma. New York: Blackwell Pub, 2002.

LINGEMAN, Richard. The Greeks Had a Word for It - But What Does It Mean?. New York Times, Nova York, 4 ago. 1969, p. 28. 
MERTON, Robert K. Social Theory and Social Structure. New York: The Free Press, 1968.

MIYAHARA, Kojiro. Charisma: From Weber to Contemporary Sociology. Sociological Inquiry, v. 53 , n. 4 , p. 368-388, oct. 1983.

PAPPAS, Takis. Political Charisma Revisited, and Reclaimed for Political Science. EUI Working Paper/RSCAS, v. 60, p. 1-16, 2011.

PARSONS, Talcott. Introduction. In: WEBER, Max. Max Weber: The Theory of Social and Economic Organization, New York: Oxford University Press, 1947. p. 3-86.

PIOVANELLI, Pierluigi. Jesus Charismatic Authority: On the Historical Applicability of a Sociological Model. Journal of the American Academy of Religion, v. 73, n. 2, p. 395-427, 2005.

RUSTOW, Dankwart A. Atatürk as Founder of a State. Dædalus, n. 97, p. 793-828, 1968.

SAMUELS, David; ZUCCO JR., Cesar. Lulismo, Petismo and the Future of Brazilian Politics. Journal of Politics in Latin America, v. 6, n. 3, p. 129-158, 2014.

SCHLUCHTER, Wolfgang. The Rise of Western Rationalism: Max Weber's Developmental History. Berkeley: University of California Press, 1981.

SCHRAM, Stuart R. Mao Tse-tung as a Charismatic Leader. Asian Survey, v. 7, n. 6, p. 383-388, 1967.

SELL, Carlos Eduardo. A liderança carismática: sobre o caráter político do populismo. Tomo, n. 23, p. 13-44, 2013.

SELL, Carlos Eduardo. Poder Instituído e Potência Subversiva: Max Weber e a dupla face da dominação carismática. Revista Brasileira de Ciências Sociais, v. 33, n. 98, p. 1-16, 2018.

SHILS, E. Charisma, order, and status. American Sociological Review, v. 30, p. 199-213, 1965.

SPINRAD, William. Charisma: A Blighted Concept and an Alternativa Formula. Political Science Quarterly, v. 106, n. 2, p. 296-311, 1991.

STRONG, Carol; KILLINGSWORTH, Matt. Stalin the Charismatic Leader? Explaining the "Cult of Personality" as a Legitimation Technique. Politics, Religion \& Ideology, v. 12, Issue 4, p. 391-411, 2011.

TARDE, Gabriel. Les Lois de L’imitation: étude sociologique. Paris: Felix Alcan, 1890.

TOODE, Ülle. Charismatic Leaders in a New Perspective: Reality in Estonia and Italy. Studies in Media and Communication, v. 8, n. 1, p. 11-24, 2020.

WEBER, Max. Economia e Sociedade. Brasília: Editora Universidade de Brasília, 2000.

WEBER, Max. Parlamento e Governo na Alemanha Reorganizada. In: WEBER, Max. Escritos Políticos. São Paulo: Folha de São Paulo, 2015a. p. 153-278. 
WEBER, Max. O Presidente do Reich. In: WEBER, Max. Escritos Políticos. São Paulo: Folha de São Paulo, 2015b. p. 309-314.

WEISS, Raquel Andrade. Efervescência, dinamogenia, e ontogênese social do sagrado. Mana, v. 19, n. 1, p. 157-179, 2013.

Recebido: 26/05/2020

Aprovado: 02/08/2020 


\section{Charismatic authority in democratic regimes}

\section{Abstract}

The article seeks to analyze the possibility of reconciling the Weberian concept of charismatic authority with contemporary democracies and with leaders who do not break with institutional norms. From Weber's exegetical analysis, we arrive at a definition of charismatic authority that is based primarily on the affective relationship of the followers with the leader because of his extraordinary character. Contesting other interpretations, we argue that this definition is compatible with democratic leaders without losing the efficiency of its application to subversive cases. Finally, in addition to Weber, we present some possible applications of the concept based on three ideal-typical elements: intensity, diffusion and direction of the charism. This model can include authoritarian and anti-authoritarian charisms and explain the behavior of followers in measures that involve their leaders.

Keyword: Charismatic authority. Democracy. Weber. Leadership. 